\title{
Indigenous Crop Production for Sustainable Livelihoods: a Case of uninga in the Rural Areas of South-Eastern Zimbabwe
}

\author{
Tenson Muyambo ${ }^{1}$ (D) Soul Shava ${ }^{2}$
}

Received: 30 September 2020 / Accepted: 3 November 2020/Published online: 27 November 2020

(C) Springer Nature Switzerland AG 2020

\begin{abstract}
South-eastern parts of Zimbabwe lie in drought-stricken agricultural region five, characterised by low and erratic rainfall patterns. To realise food security people in the region have resorted to growing drought resistant crops such as sorghum. The recent observations are that the success of sorghum as a drought resistant crop is accompanied by ambivalence as some people view the crop to be unsuitable as a staple food while others rely on it to cope with food insecurity. Some families have resorted to farming cash crops such as cotton and use the dividends to buy maize meal as the staple food. However, recently some farmers have started intensive production of uninga, an indigenous crop which had almost become extinct among the Ndau people (an ethnic grouping of Ndau-speaking) of south-eastern Zimbabwe. The production of this crop is under-researched and understudied in Zimbabwe. To fill this lacuna, we adopted a participatory case study research approach to explore the nature and scope of uninga production. An Afrocentric-postcolonial lens was employed to investigate the factors for its resurgence after decades of absence in the agricultural crop basket. We found that the crop which used to be largely cultivated by women in the past, had become a 'must-plant' crop for all gender owing to its high demand on the market, especially in Mozambique.
\end{abstract}

Keywords Ndau community · Indigenous crop · Uninga - Cash crop · Drought resistant · South-Eastern Zimbabwe

Uninga is a Ndau word referring to sesame (Sesamum indicum). In other languages like Zezuru and Karanga, uninga is known by the term runinga. Among the Ndau, this crop was traditionally a female crop planted by women among other crops such as sorghum, millet, rapoko, maize but not as the main crop. Women would then use it to flavour their meals. In most cases women would plant it on a very small-scale for domestic purposes only. No males were involved in its production since its uses were confined to the kitchen as a relish flavour.

Tenson Muyambo

tmuyambo@gzu.ac.zw

Extended author information available on the last page of the article 


\section{Introduction}

The production of indigenous crops in Africa has been largely on a small-scale perspective. Rajasekaran (1993) notes that over $90 \%$ of Africa's agricultural output is by small-scale (less than $5 \mathrm{ha}$ ) farmers who have for centuries sustained their food supply through a considerable wealth of indigenous knowledge on how to harness both natural and socio-economic factors of production. The production of indigenous crops has experienced a sharp decline in Africa due to colonisation which saw the introduction of exotic cash crops. Bell (2000) and Arthur (2003) observed that colonialism destroyed the essence of African food security by introducing exotic crops such as wheat, barley, maize, rice and monocultural agricultural systems meant for the external market at the expense of sustainable community livelihoods.

South eastern Zimbabwe is an arid region experiencing perennial droughts, an aspect that has made many households abandon the production of crops such as maize, an imported crop that has become a staple crop for most Zimbabweans. This has resulted in households resorting to more drought tolerant cash crops such as cotton and the revisiting of the production of indigenous uninga (sesame). The shift to cash crops, though ushered in African communities by colonialism, has become a coping strategy in drought-stricken areas of south eastern Zimbabwe. The argument is that people farm cash crops and get money, which they in turn use to buy the staple food from shops or the Grain Marketing Board (GMB). This set-up has not only seen the resurgence of uninga but the involvement of males in its production.

At the time of this study, the communities in the study area were experiencing perennial droughts and food insecurity was rife. Under such dire circumstances, malnutrition was a major concern for health agencies. As a gap-filling measure, the communities resorted to getting food handouts from Non-Governmental Organisations (NGOs) under the Food for Work Programmes, where people engaged in some local community development activities such as roads, bridges, dip tanks maintenance, in return for monthly food handouts. Cotton production, as one coping strategy by local communities, had its own challenges. Apart from its labour intensive nature and its high input costs, cotton had also become a liability in that it succumbed to the extreme drought conditions. Another challenge was that, instead of paying the farmers money, the cotton buying companies such as the Cotton Company of Zimbabwe were paying them in the form of food hampers or grocery to the farmers, a move that irked most farmers in the areas. Resultantly, households had to diversify their agricultural crops. It is in this context that uninga (a traditionally small-scale crop produced by women for domestic chores) was transformed from being a women's crop into an all-gender crop.

Uninga (sesame), an oilseed crop of the family of Pedaliaceae, is one of the oldest cultivated crops of the world with total production of 3.3 million tons (FAOSTAT data 2008). Sesame seeds are rich in oil (50-60\%), protein $(25 \%)$, unsaturated fatty acids, vitamins, minerals, and folic acid. They are used in baking, candy making, health-care products, and biomedicine. Nearly $70 \%$ of sesame seeds are processed into oil (Morris 2002). Sesame oil has numerous health benefits as it contains potent natural antioxidants such as sesamolin, sesamin, and sesamol (Brar and Ahuja 1997). It is also a source of linoleic acid. It has low levels of saturated fatty acids (15\%) and was recently found to be beneficial in lowering cholesterol levels and hypertension (Sankar et al. 2004; Frank 2005). Sesame also reduces the incidence of certain cancers 
(Hibasami et al. 2000; Miyahara et al. 2001). Production of sesame is severely affected by biotic as well as abiotic constraints, which mainly include fungal diseases, photosensitivity, and early senescence resulting in losses ranging from 10 to $90 \%$ of the yield (Miyahara et al. (2001). While in Zimbabwe many do not know sesame, it is of great importance to many countries such as India, China and Sudan (Nyoni 2018).

Its cultivation is limited around Zimbabwe, where it is grown as a minor crop by smallholder farmers. Many farmers have neglected its production due limited knowledge by the industry, lack of appreciation by consumers and lack of public funding for research towards its improvement for cultivation in the local environments (Nyoni 2018). This lack of knowledge can be attributed to the limited publicity of the crop in Zimbabwe. Be that as it may, the past three to four years have witnessed an increased production of the crop, though still on a small-scale level, especially in south-eastern parts of Zimbabwe. This article intends to extend this publicity by documenting the local knowledge and cultivation of the crop through research for a wider readership and dissemination. It is against this backdrop that this article examines the factors leading to the sudden interest and increase in the production of uninga in the study area with a view to establishing the crop's nature and scope of production, its shift from being a female crop to all gender crop, its level of production and its impact on livelihoods. The study intended to understand the crop's dynamics from an indigenous small-scale production perspective in order to inform policy towards its large-scale production in Zimbabwe.

\section{Methodology}

Considering that uninga is an indigenous community-based crop, the study adopted a participatory case study approach to investigate the crop's nature and scope. The participatory approach was adopted because it enables development practitioners, government officials, researchers in partnership with local people to work together (Vunyingah and Kaya 2016). Vunyingah and Kaya (2016:186) further state that the participatory approach "provides a shift of research thinking from doing research on people to doing research with people". Kaya and Koitsiwe (2016) also confirm that the participatory research process involves a partnership between the researcher and those being researched, a shift from the past where researchers never involved the community knowledge holders in the research process (Macaulay 2007). In this study, community knowledge holders, local uninga farmers (female and male), traditional leaders, government agricultural extension officers, community elders and NGOs operating in the community were actively involved in the research process. Moreover, in an effort to ensure maximum participation by the respondents, the study was conducted in Ndau, the local language of the study area.

A purposive sample of ten uninga farmers ( 5 female and 5 male), five traditional leaders (all male), five community elders ( 3 female and 2 male), one Agritex officer and one NGO participated in the study. The five traditional leaders were all men because the study community is largely patriarchal. The involvement of women participants/ respondents was premised on the fact that they are key local knowledge holders since uninga was traditionally their crop meant for domestic uses as compared to other crops that were dominated by men. The people included were known to have been involved 
in specific experiences related to the research problem, that is the uninga production. In conceptualising a case study, Conrad (2002) observes:

Rather than using large samples and following a rigid protocol to examine a limited number of variables, case study methods involve an in-depth examination of a single instance or event. They provide a systematic way of looking at events, collecting data, analysing information and reporting the results. As a result, the researcher may gain a sharpened understanding of why the instance happened as it did, and what might become important to look at more extensively in future research.

The selection of this case study was purposive, because the study targeted rich information sites (Patton 2002) who had some experience and knowledge uninga production. Berelson (2000) defines a purposive as a non-representative subset of some larger population and is constructed to serve a very specific need or purpose. The study was a qualitative one, using focus group discussions, interviews and observations as data collection tools. The respondents' views were recorded verbatim and translated for non-Ndau speakers. Interview and observation notes were typed, and content analysis conducted. Data were analysed using SPSS (Babbie 2004).

\section{Findings and Discussion}

\section{The Socio-Economic and Demographic Characteristics of the Respondents in the Ndau Community}

The purpose of gathering data on socio-economic and demographic characteristics of the respondents/participants (used interchangeably hereinafter) was to describe the characteristics of the respondents in terms of their age groups, gender, marital status as well as their level of 'formal' education. The results are presented below.

The study found out that the majority of the respondents $(90 \%)$ were in the age group of 35 years and above. The focus group discussions held with this age group revealed that the respondents had information on uninga as either having uninga personal plots or having practical experience on how uninga was produced. The respondents' experience with uninga production ranged from 1 to 3 years since the crop had just resurfaced from Mozambique in the past 4 years. Since the marriage institution is highly regarded in Shona communities (Bourdillon 1991:36), of which the Ndau people is one of them, it was also prudent to establish the respondents' marital status. The majority of the respondents, both male (100\%) and female (100\%), were married, with $20 \%$ of the female respondents being widowed. Interviews and focus group discussions held with the respondents indicated that the respondents were directly involved in the farming of uninga and were highly knowledgeable about it.

Probing into the participants' educational backgrounds, the study discovered that most of the respondents, both male $(62 \%)$ and female $(56 \%)$ had not attained Ordinary Level qualifications, commonly known as 'Form Four' or 'O' level. Some of the respondents had no formal education at all. However, interviews with them revealed that they had a wide knowledge on uninga production owing to their experience gained over years of trial and error. 


\section{The Nature and Scope of uninga in the Ndau Community}

Face-to-face interviews and focus group discussions were used to explore participants' understanding of uninga as a crop of the Ndau community.

The respondents revealed that uninga was nthikiti (loosely translated as seeds) that are used traditionally for adding flavour to relish. They indicated that the crop was a broadleaf that grows to a height of 1.5 to $2 \mathrm{~m}$, depending on the variety and growing conditions. Some of the respondents stated that the crop can be more than $2 \mathrm{~m}$ if grown when the rains are still heavy. It grows without flowering nor producing the pods. It was also indicated that the most common variety of the crop in the communities under study was the white seeded variety compared to the dark seeded one.

Despite its traditional use as a relish flavour or oil, the respondents revealed that the crop was almost forgotten but had resurfaced over the past three to four years. They indicated that its reintroduction came from neighbouring Mozambique, where smallscale farmers were making a lucrative business out of it. Adopting uninga production from the Mozambican small-scale farmers (most Ndau communities share the border with Mozambique and have relatives across the border (MacGonagle 2007, Konyana 2017 and Muyambo 2019)), the participants indicated that the crop was now the pride of many including male small-scale farmers.

\section{Indigenous uninga Production Management Systems}

The study sought to understand why uninga had suddenly resurfaced and how it was cultivated and managed among the Ndau people of Chipinge district, particularly in Musikavanhu and Chipinge South constituencies. Participants revealed that uninga was traditionally planted in between other crops (intercropping) such as maize. This was done during weeding the main crop, especially during the month of February, called Mushekwa in Ndau language. This is a period when the rains are not as heavy as they were during the onset of the rainy season. One female farmer indicated that they planted uninga among maize, millet, sorghum, pumpkins, cassava and beans in good years.

However, due to its becoming a cash crop, uninga was no longer cultivated using the mixed or intercropping methods. Most households had separate plots for cultivating the crop. The respondents revealed that they prepared the land well on time and waited for the rains to subside a bit and then planted the crop. They indicated that the crop required less rains compared to other crops and took about one to one and half months to mature. What this means is that it is an early maturing and easy crop to cultivate.

On land preparation, the participants stated that land on which uninga was to be sown should be thoroughly ploughed and made ready for sowing the crop. Uninga was sown or planted manually by hand. They stated that when the piece of land prepared by an animal drawn plough was ready, the small uninga seeds were either mixed with sand or soil and then broadcast thinly over a flat surface. An animal drawn light tree branch was used to cover the seeds ensuring that it was only light soil that covers the seeds, lest it did not germinate if covered with heavy soil. The seeds were said to germinate between 5 and 7 days. When seeds had germinated the farmer was supposed to check his or her crop for pests and other predators. When about $5 \mathrm{~cm}$ the farmer may spray insecticides to ensure there are no pests. At this stage there were common pests that the participants identified as zvimatemwe zvakasvipa (black bugs). These bugs were 
sprayed using pesticides. Other participants indicated that the crop's stems may be affected by a whitish substance that the farmers had no name for. Again, they sprayed the crop when this occurs. It was also interesting to note that some farmers indicated that ashes were used in some instances to prevent these pests and whitish substance. This was an indigenous knowledge practice being used. In a study carried out in Chimanimani on indigenous knowledge systems and crop management and grain storage, Sithole (2020) states that ash is a resource that local communities use in managing and storing their crops. As the farmer continued to monitor his/her crop, weeding was done when necessary, and the participants revealed that the crop was weeded once or twice before maturing. When the crop was mature the stem and leaves turned yellowish-brown in colour.

When a farmer discovered the crop's stems and leaves turning yellowish-brown in colour, he/she had to begin harvesting the crop. The respondents stated that this was the most critical part of the uninga production. They indicated that timely harvesting and stacking was essential for the quality of the harvest and that it decreased losses due to shattering in cases of labor limitations. In harvesting uninga, the mature plants were cut, bundled, and stacked to dry. In some areas, the shocks were left in the field but this was very rare in the communities under study due to the high risk of theft. In other areas the bundles were moved to a threshing floor - a hard surface traditionally made using cow dung. However, caution was recommended to minimise seed loss during transportation to the threshing ground/floor. The modern threshing ground was generally a concrete floor or a canvas sheet to keep the seed free from soil, gravel, dust and other inert materials that reduce quality of sesame seed (Terefe et al. 2012). As the plants dried the capsules opened and some of the seed fell out. If the harvested crop was on a threshing floor, the stacks ould be moved around every few days, and the seeds were winnowed and collected.

\section{Indigenous uninga Post-Harvest Management Systems}

Post-harvest management of uninga was crucial for food security. The participating uninga farmers reported that after the seeds were collected from the thrashing floor, they are stocked in fifty-kilogram bags or sacks ready for the market or storage. The majority of respondents also reported that, due to the small size and flat shape of uninga seeds, it was difficult for ambient and fresh air to circulate during storage. This is also confirmed by Terefe et al. (2012) when they state that it is therefore recommended that the seed be thrashed when as dry as possible and stored at moisture content of below $7 \%$. The respondents revealed that traditionally, the crop was stored in clay pots or calabashes because it was produced on a small scale. However, since the crop was now mass produced compared to what used to obtain, the seeds were now stored in sacks. It was reported that once the seeds were stored in the sacks, the farmer would then periodically check for pests. Most of the interviewees revealed that uninga was cheaper and relatively easy to store since it was not attacked by troublesome grain storage pests.

The respondents stated that storage warehouses/b must be clean, and sacks/bags must be free of insect pests. Equipment as well as working and drying surfaces, preparation and storage rooms should be cleaned regularly, and all sweepings collected from time to time. Bags/sacks had to be stacked or piled up systematically to ease counting and removing, inspection and management, with a minimum of $2 \mathrm{~m}$ spacing 
between stacks. According to Terefe et al. (2012), stacked sesame should be stored in a dark place at low temperatures (below $18{ }^{\circ} \mathrm{C}$ ) and low relative humidity. The participants revealed that under optimum storage conditions, uninga seeds could be stored for up to one year. However, the respondents were quick to state that it was very important to protect the seeds from loss of aroma and undesirable smells and tastes from its surroundings. Therefore, storing pesticides, fuel, oil, and other odorizing agents together with uninga in the same space was not permitted. Empty bags, tarpaulins and other accessories that were not in use had to be stored separately.

Each stack had to be inspected at least once in two weeks to check whether seeds were damaged by insect, rodents, dampness or moisture. If damage was observed, necessary measures had to be taken. For damage by insects, the farmers fumigated with Aluminum phosphate tablets (APT) at the rate of 3 tablets per ton sesame seed. If rats were causing damage, their points of entry had to be identified and necessary measures taken to prevent their ingress. If dampness was observed either due to seepage of water from the floor or from the walls of the store or due to leakage of rainwater, the source of dampness or rain had to be removed. For safe long-term storage, all bags with holes in the stacks had to be either suitably repaired or replaced during periodic inspections.

\section{The Nutritional Value of uninga and its Efficacy as Food Security}

The study established that uninga was a valuable crop that was an alternative food supplement. Although the respondents were not very clear as to the nutritional components of the crop, they were quick to state that the crop was used a substitute for staple foods in times of hunger. One respondent stated, "uninga hunoitwa undu vanthu vorya vomwa mvura. Ukamwa mvura usingarutsi zvatoita kwaakuzorya sadza madeekoni (edible powder prepared from sesame was used taken as a snack and washed down with water. This gave required energy during the day and people will have dinner as the main meal). This meant that by skipping major meals during the day and using powdered uninga as a snack people would save their food reserves and the limited reserves would last them for many days. Although the respondents could not specifically identify the nutrients in uninga, there was agreement that "uninga unogwinyisa" (sesame was healthy food and provided energy). Terefe et al. (2012:6) state that nutritionally the sesame seeds contain $22-35 \%$ protein, $23 \%$ carbohydrate and $3-4 \%$ mineral. The respondents went on to state that traditionally undu (sesame powder) was used to wean babies from sucking. They revealed that once the child takes the powder, he/she would not think of breastfeed. He/she would spend the day drinking water and playing with others. This means the child would never hunger for breastfeed.

It also came out that $u$ ndu was not only for the young. It was also for the old. At one homestead where we were interviewing a farmer, $u n d u$ was prepared and we were given some. It made us thirsty and we were never hungry during the day as we continued taking water-a strategy communities use to save their food reserves in lean years. The respondents revealed that during drought periods uninga provided a safety net in terms of food insecurity. This is because the uninga crop requires very low rainfall. Nyoni (2018) concurs to this by arguing that sesame is a drought tolerant crop, making it suitable for cultivation in drought-prone areas of Zimbabwe. Uninga was regarded by the respondents as an alternative food to sadza (the Ndau staple food) 
during lunch. It was for that reason that most households in the study area farmed uninga apart from the economic benefits that the long-forgotten crop provided for the households.

\section{The Socio-Economic Significance of uninga within the Ndau Community}

Uninga does very well in tropical environments and the respondents' forefathers used to grow it successfully. However, many had since forgotten it over time prior to its reemergence as a commercial crop. It has a great potential for commercial use in Zimbabwe and should be considered as a crop option in dry regions. However, much publicity and research focusing on its genetic improvement is required to tap into its potential benefits. Africa is said to have 2.80 million hectares under sesame after Asia which has 4,48 million hectares of the total world production area of 7,55 million hectares (The Herald Reporter 2014).

The participants indicated that uninga had socio-economic benefits for the Ndau community. Before it became a cash crop, uninga was of a cultural importance. For example, it offered females a social status. An elderly female participant revealed that one would be considered a wise woman by planting uninga in her field among other crops. She further indicated that it was a foolish and lazy woman who would not do that and who would prepare food without the uninga flavor, nthikiti, a delicacy most cherished amongst Ndau households. The crop was traditionally planted in between other crops such as maize, sorghum and millet. The planting was done mostly by women during weeding the main crop of the field. The seeds were then harvested, roasted and pound into a powder commonly known as $u n d u$ among the Ndau. Undu is then used in relish preparation as both an oil and flavourant to the relish. An undu flavoured relish is a delicacy for families among the Ndau households. The elderly female participants derived pride and selfesteem in preparing this relish. Although the participants indicated that the undu powder was no longer as common as it was in the yesteryears, it was still a marvel for the elderly females to prepare it for their households.

With the crop changing status from being a subsistence crop to a cash crop, the local people's 'cash cow', the economic benefits of the crop were vividly explained by the respondents. Similar to Bourdillon's (1991:81) observation of the positive effects of commercial farming among the Shona after independence in the early 1980 s where annual income for households ranged from $\$ 1600$ to several thousands, the respondents were unanimous in noting that uninga production had changed their livelihoods. They revealed that they were earning United States Dollars (US\$) or South African Rands (R) from selling their uninga produce. They were selling $1 \mathrm{~kg}$ quantities of uninga for R10-20 in a depressed Zimbabwean economy. Earning foreign currency enabled them to send their children to school, buy them stationery, build durable structures like houses of brick and cement as opposed to poll and dagga. With some households realising annual produce of up to $1000 \mathrm{~kg}$ of uninga, their socio-economic status was greatly improving. The lucrative business therein had resulted in many households resorting to cultivating uninga at the expense of other cash crops such as cotton, which they ditched for being labour intensive and less paying on the market. It was also noted during fieldwork that, although the smallscale farmers were counting their benefits in terms of the number of bags or buckets, they realised from their uninga production, they were not very clear on the annual figures in terms of their total production and the dividends realised. 
In other countries, the crop is doing very well and contributes immensely to the countries' national Gross Domestic Product (GDP). For example, Ethiopia, where sesame is the second most profitable export after coffee, is among the top producers of the seed in the world, with exports amounting to \$388 million reported in 2017 (Nyoni 2018). Other producers within the Southern African Development Community and Common Market for Eastern and Southern Africa region include Mozambique and Tanzania (Nyoni 2018). Nyoni further states that countries where sesame is an integral part of national cuisines such as Egypt, Vietnam, Israel, Turkey and Hong Kong have reported increased imports of the product. Despite the global price volatility, volumes of sesame seed traded between 2013 to 2016 increased by 40,3\% from 1,4 million tons to 2,1 million tons over the three-year period, according to the Trade Map (Nyoni 2018). This crop, as statistics indicate, can be a 'cash cow' for Zimbabwe if produced at a large scale. Quoting figures from Trade Map, ZimTrade revealed that Zimbabwe exported sesame seed worth \$1,8 million in 2017 to Mozambique and Egypt. This, statistically, is no mean achievement for a country that desperately needs to export in order to realise foreign currency for its imports.

\section{Challenges of uninga Production among the Ndau Community}

The study revealed that more than $70 \%$ of the respondents, both male and female, knew traditional means of farming the crop. However, indications were that there was no zeal amongst the small-scale farmers to seriously put most of their pieces of land under uninga production. Despite their acceptance that uninga had indeed changed their lifestyles, the small-scale farmers were still either reluctant or lacked knowledge on how to increase their crop production. Some bemoaned lack of land as all siblings had to share the small land bequeathed to them by their parents. Nationally, ZimTrade found that the low recognition of sesame seed as a viable crop for Zimbabwe is likely due to the lack of knowledge on the farming methods, benefits, and potential markets of the crop. In terms of markets, the farmers indicated that almost $100 \%$ of their buyers were from neigbouring Mozambique. The buyers moved around their households buying the crop. The farmers revealed that they had no power to negotiate the prices of the crop since this was determined by the buyers. Upon further probing on the issue of the markets, the farmers bemoaned the lack of buyer competition for the crop, leaving them at the mercy of the Mozambican market. In their view, competitors would force the Mozambican buyers review their prize of R10-20 per a kilogram of the crop.

The farmers were also suspicious of Cotton Company of Zimbabwe who are also into uninga growing promotion and buying. The farmers indicated that their experiences with Cotton Company in cotton production in the region were an eye-opener. When it came to uninga, the farmers were reluctant to deal with Cotton Company. They complained of its cotton pricing and paying modalities. Despite the Mozambican buyers paying R10-20 per kilogram in cash, the farmers felt they were better than the Cotton Company who used to pay them in the Zimbabwean dollars through eco-cash. The farmers revealed that, in addition to not paying in cash, the eco-cash model charged them high transaction charges, thereby prejudicing them of their hard-earned money. Because of these reasons, the farmers did not want to do business with the Cotton Company. 
Upon revisiting the respondents recently to verify certain ideas raised during field work, we were told that the buying price had drastically gone down to eight Rands (R8) per kilogram. The respondents attributed this to the coronavirus pandemic which had closed the Zimbabwe-Mozambique border whereby Indians who could offer better competitive prizes could not make it into Zimbabwe. The Indian buyers had to rely on middle-men, commonly labelled by the respondents as makoronyera (crooks). The makoronyera brought down the prices for them to gain and cheated the small-scale farmers. One respondent reiterated thus:

\section{Uninga watiruzisa gore rino. Makoronyera awanda saka apana nemare} yatinoona apa. MaIndia aisitenga zvakanaka ari kutuma makoronyera aya ari kutibira. [We have made losses in the sesame production. There are many middle-men, so the sesame price has gone down. Indians send middle-men to buy who, in turn, manipulate the prizes for their benefit].

This above excerpt is indicative of the loss of confidence amongst the farmers to continue farming uninga. They feel they are being short-changed and the farmer in the final analysis cannot continue to farm where he/she does not realise the fruits of his/her labour. It is the middle-men who are benefitting, leaving the small-scale farmer with nothing to motivate him/her to continue farming uninga.

The respondents revealed that they had no assistance in their uninga production from government agricultural research and development institutions. The agricultural research agenda in Zimbabwe had ignored and neglected the needs of the small-scale uninga farmers. They indicated that there were no agricultural extension officers, specifically for uninga production. This lack of attention to indigenous crops seems to be the trend with African governments. For example, in a study carried out in Cameroon on sorghum production, Vunyingah \& Kaya (2016:190) stated that "All the respondent sorghum farmers, both male and female, complained that they did not receive any form of government support and their local knowledge was not taken seriously by most development agencies including extension officers".

\section{Conclusion}

This article discussed the resurgence of uninga production in south-eastern Zimbabwe. It noted that the resurgence of the long forgotten indigenous crop was because of its recent 'cash cow' status, where it has not only nutritiously improved the households' diet but has brought economic benefits to small-scale farmers in Chipinge. The crop's significance had grown from its traditional role as a relish flavor to a cash crop that had a double function: use as a supplement of the staple food during hunger and a major economic source of livelihood for most households in the study areas. The article also highlighted the problems that uninga small-scale farmers have to contend with despite the benefits that have accrued with the crop's production, chief among them being lack of support from agricultural research and development agencies and the advent of middle-men buyers who short-change the farmers during the coronavirus pandemic era. 


\section{Recommendations}

The following recommendations were made:

1. There is the need for the government to develop relevant policy and strategies to promote the cultivation and use of uninga for purposes of food security and economic resuscitation in line with its Vision 2030, where Zimbabwe needs to be a middle-class economy by 2030 . This has to be coupled with training of the uninga small-scale farmers to realise their full potential as well as availing enough land to farmers under the ongoing land reform.

2. Given the role of middle-men buyers, government is recommended to take the production of uninga seriously, promote its marketing and regulate its pricing just like it does for other crops such as cotton and tobacco.

3. The study recommends that research and development agencies should support uninga small-scale farmers, especially women whose interest and expertise in the crop production was phenomenal in the study, by providing the necessary knowledge and finding favourable and competitive markets for the farmers. Thirdly, given the challenges encountered by the farmers, the study recommends contract farming where contract growers are not only guaranteed of viable markets but all that is involved the crop production. Fourthly, in order to maintain sustainability in the crop production in a dry region where even low rainfall is very erratic like the study area, the study recommends putting the crop production under irrigation.

\section{Compliance with Ethical Standards}

Conflicts of Interests/ Competing Interests On behalf of all authors, the corresponding author states that there is no conflict of interest.

Ethics Approval Not applicable.

Consent to Participate This was obtained through participants verbally agreeing and in some instances consent forms were filled.

\section{References}

Arthur, P. (2003). Traditional environmental knowledge: A resource to manage and share. Development Journal of the Society for International Development, 4(2), 24-29.

Babbie, E. (2004). The practice of social research. 10th Edition. Vienna: Thomson and Wadsworth Publishers.

Bell, M. (2000). The exploitation of indigenous knowledge or the indigenous exploitation of knowledge: Whose use of what for what? Journal of Development Studies, 10(2), 44-50.

Berelson, B. (2000). Content analysis in communication research. New York: Hafner Publishing Company. Bourdillon, M. F. C. (1991). The Shona peoples: An ethnography of the contemporary Shona, with special reference to their religion. Revised Edition. Gweru: Mambo Press.

Brar, G. S., \& Ahuja, L. (1997). Sesame: Its culture, genetics, breeding and biochemistry. Ann Rev Plant Sci, $1,245-313$.

Conrad, P. (2002). Case study research, design and method. Thousand Oaks, CA: Sage.

Frank, J. (2005). Beyond vitamin E supplementation: An alternative strategy to improve vitamin status. Journal of Plant Physiology, 162, 834-843. 
Hibasami, H., Fujikawa, T., Takeda, H., Nishibe, S., Sato, T., Fujisawa, T., \& Nakashima, K. (2000). Induction of apoptosis by Acanthopanax senticosus harms and its component, sesamin in human stomach cancer KATO III cells. Oncology Reports, 7, 1213-1216.

Kaya, H. O., \& Koitsiwe, M. (2016). African indigenous knowledge systems and natural disaster Management in North West Province, South Africa. Journal of Human Ecology, 53(2), 101-105.

Konyana, E. (2017). When culture and the law meet: an ethical analysis of the interplay between the domestic violence act and the traditional beliefs and cultural practices of the Ndau people in Zimbabwe. South Africa: PhD thesis, University of KwaZulu Natal.

Macaulay, A. C. (2007). Promoting participatory research by family physicians. Annals of Family Medicine, 5(6), 557-560.

MacGonagle, E. (2007). Crafting identity in Zimbabwe and Mozambique. Rochester: University of Rochester Press.

Miyahara, Y., Hibasami, H., Katsuzaki, H., Imai, K., \& Komiya, T. (2001). Sesamolin from sesame seeds inhibits proliferation by inducing apoptosis in human lymphoid leukemia Molt4B cells. International Journal of Molecular Medicine, 7, 369-371.

Morris, J. B. (2002). Food, industrial, nutraceutical and pharmaceutical uses of sesame genetic resources. In J. Janick \& A. Whipkey (Eds.), Trends in new crops and new uses (pp. 153-156). Alexandria, VA: ASHS.

Muyambo, T. (2019). Indigenous Knowledge Systems of the Ndau people of Manicaland province in Zimbabwe: A case study of bota reshupa. South Africa: PhD thesis, University of KwaZulu Natal.

Nyoni, M. (2018). Zim farmers urged to grow sesame seeds. Newsday, 18 July.

Rajasekaran, B. (1993). A framework for incorporating indigenous knowledge systems into agricultural research and extension organisations for sustainable agricultural development in India. $\mathrm{PhD}$ thesis. Iowa State University.

Reporter, A. (2014). Sesame: Long-forgotten crop. The Herald., (18 July).

Sankar, D. Sambandam, G. Rao, M. R, \& Pugalendi, K. V. (2004). Impact of sesame oil on nifedipine in modulating oxidative stress and electrolytes in hypersensitive patients. Asia Pacific Journal of Clinical Nutrition, 13, 107.

Sithole, P. M. (2020). Indigenous knowledge Systems in Crop Management and Grain Storage in Chimanimani District of Zimbabwe. Southern African Journal of Environmental Education, 36, 21-32.

Terefe, G., Wakjira, A., Berhe, M., \& Tadesse, H. (2012). Sesame production manual. EIAR, 1-46.

Vunyingah, M., \& Kaya, H. O. (2016). Sorghum as an indigenous drought resistant crop for food security in the north West Province of Cameroon. Journal of Social Sciences, 46(2), 185-191.

Publisher's Note Springer Nature remains neutral with regard to jurisdictional claims in published maps and institutional affiliations.

\section{Affiliations}

\section{Tenson Muyambo ${ }^{1} \cdot$ Soul Shava ${ }^{2}$}

1 Department of Teacher Development, Great Zimbabwe University, Masvingo, Zimbabwe

2 Department of Science and Technology Education, University of South Africa, Pretoria, South Africa 